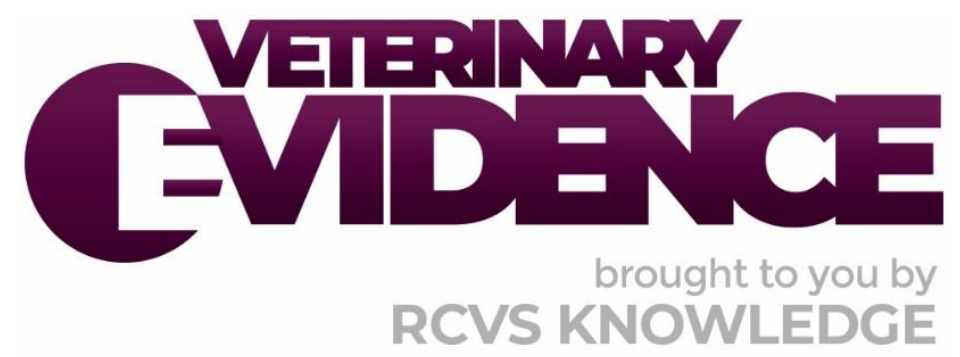

\title{
The Effects of Biannual Equine Influenza Vaccine on Performance in Adult Horses
}

\author{
A Knowledge Summary by
}

Emma Shipman BVetMed, MSc, DipACVIM, CertVA, MRCVS ${ }^{*}$

\footnotetext{
${ }^{1}$ School of Veterinary Medicine and Science, University of Nottingham, Sutton Bonington Campus, Leicestershire, LE12 5RD

*Corresponding Author (emma.shipman@nottingham.ac.uk)
}

ISSN: 2396-9776

Published: 26 Jul 2019

in: Vol 4, Issue 3

DOI: http://dx.doi.org/10.18849/ve.v4i3.196

Reviewed by: Polly Compston (BSc (Hons), BVM\&S, MSc, MRCVS) and Margaret Nolan (BSc, MSc, PhD)

Next Review Date: May 1st 2020 


\section{KNOWLEDGE SUMMARY}

\section{PICO question}

In three day event horses, does biannual routine influenza vaccination compared to annual routine influenza vaccination reduce performance levels?

\section{Clinical bottom line}

There is no evidence that biannual equine influenza vaccination compared to annual booster vaccination in three day event horses is associated with reduced performance.

A group of five studies published over an 11 year period from one veterinary hospital were evaluated. In adult warmblood horses there is weak evidence that exercise in the 28 day period post booster vaccination for equine influenza and equine herpes virus 1 and 4 (EHV1\&4), is associated with changes in physical and clinical pathophysiological parameters including total red blood cell (RBC) count, neutrophil and lymphocyte count, fibrinogen concentration and serum proteins. These changes occurred at variable time points in the 14 days post exercise and values were not outside the published reference ranges for the reporting laboratories where published. Athletic performance of the horses was not evaluated.

No recommendations for equine influenza vaccination protocols in three day event horses can be made from the evidence.

\section{The evidence}

There is no retrospective or prospective evidence examining performance in three day event horses after annual or biannual booster vaccination against equine influenza virus. There is no evidence examining performance levels in three day event horses after booster vaccination against equine influenza virus. There is a small amount of evidence, and the quality of the evidence is low, evaluating clinical and clinicopathological data that may relate to performance in adult warmblood horses undergoing booster vaccination and subsequent exercise. These five randomised controlled trials were conducted at one veterinary teaching hospital using a small number of adult warmblood horses over an 11 year period. The evidence evaluated may not be applicable outside the experimental group of 15 horses and some horses may have been included in more than one of the studies.

\section{Summary of the evidence}

\section{(A) Gundasheva (2015)}

\begin{tabular}{|r|r|}
\hline Population: & Adult Hanoverian geldings at one Bulgarian veterinary hospital \\
\hline Sample size: & 15 horses \\
\hline Intervention details: & - Vaccinated for EHV1\&4 and equine influenza virus (EIV) 12 \\
& months after initial vaccination [n=6] \\
& Vaccinated for EHV1\&4 and El 12 months after initial \\
& vaccination and submitted to physical exercise for 4 days \\
& commencing 14 days after revaccination [n=6] \\
& Control group of unvaccinated animals [n=3] \\
\hline
\end{tabular}




\begin{tabular}{|c|c|}
\hline Study design: & Randomised controlled trial \\
\hline Outcome studied: & $\begin{array}{l}\text { Erythron parameters, heart and respiratory rates were determined } \\
0 \mathrm{~h}, 2 \mathrm{~h} \text {, and day } 14 \text { and } 17 \text { after booster vaccination and days } 1,2,4 \\
\text { and } 11 \text { after commencement of exercise. Results were presented as } \\
\text { mean }+/ \text { - standard error of mean (SEM) }\end{array}$ \\
\hline $\begin{array}{l}\text { Main findings: } \\
\text { (relevant to PICO question): }\end{array}$ & $\begin{array}{l}\text { 1. All erythron parameters of all groups remained within the } \\
\text { published reference ranges for the study period } \\
\text { 2. Heart rate and respiratory rate were significantly increased } \\
\text { in the physical exercise group } 0 \mathrm{~h} \text { and } 2 \mathrm{~h} \text { post exercise } \\
\text { 3. RBC count was statistically different between vaccine and } \\
\text { vaccine plus exercise groups, increasing in the vaccine and } \\
\text { exercise group on day } 4 \text { after cessation of physical exercise } \\
\text { but not on day } 2 \text { or } 11\end{array}$ \\
\hline Limitations: & $\begin{array}{l}\text { - } \quad \text { Small group sizes } \\
\text { - Whether horses in the intervention groups had received } \\
\text { primary and/or booster vaccinations against EHV1\&4 and } \\
\text { EIV is not reported } \\
\text { - } \quad \text { Randomisation process was not described } \\
\text { - } \quad \text { Reported reference ranges are laboratory specific } \\
\text { - } \quad \text { detail } \\
\text { Level of preceding fitness prior to study inclusion was not } \\
\text { reported }\end{array}$ \\
\hline
\end{tabular}

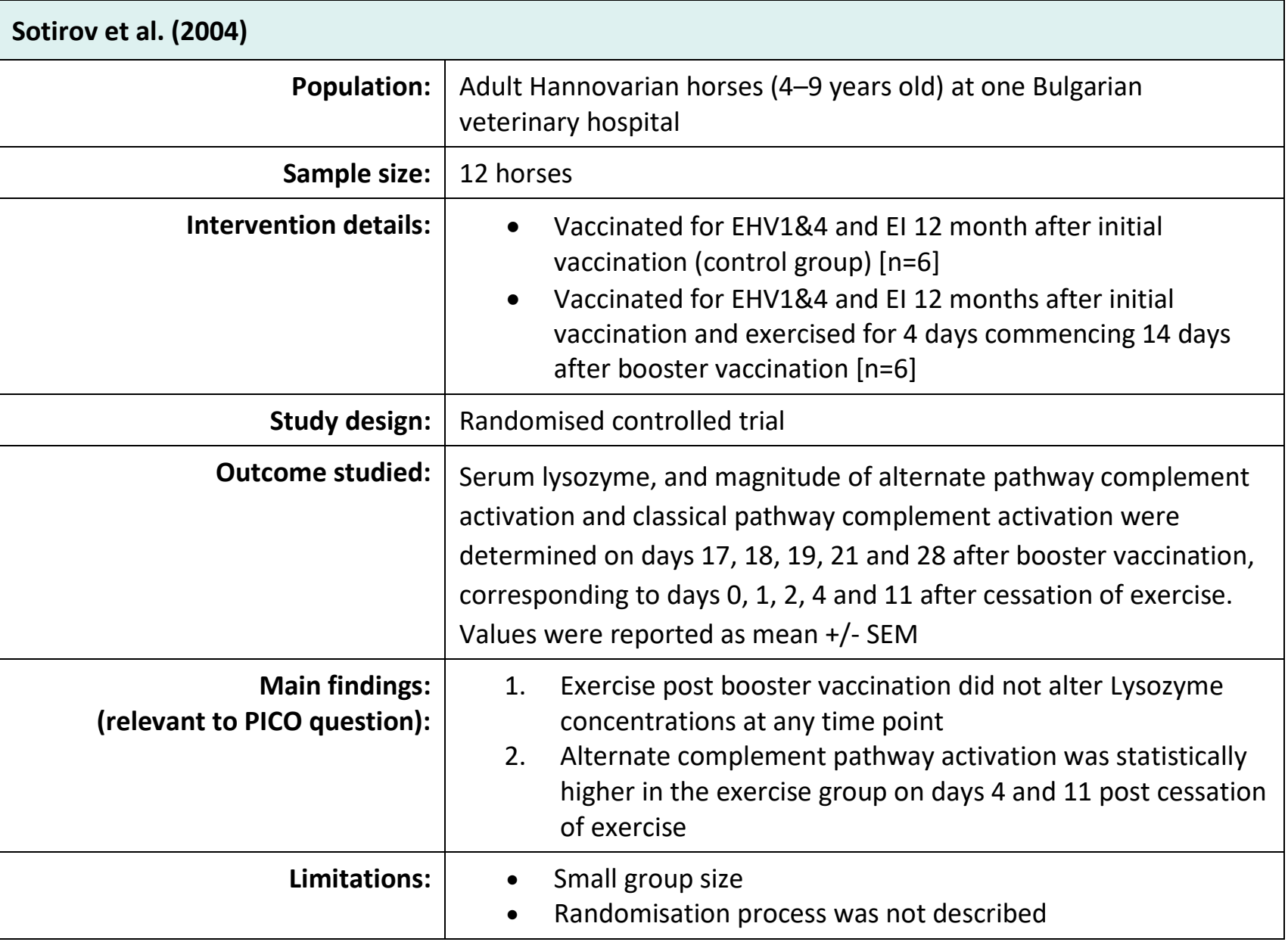




\begin{tabular}{|l|l|}
\hline & $\begin{array}{l}\text { Level of preceding fitness prior to study inclusion was not } \\
\text { reported for either group } \\
\text { Prior vaccination status of the horses was not discussed in } \\
\text { detail }\end{array}$ \\
\hline
\end{tabular}

\begin{tabular}{|c|c|}
\hline \multicolumn{2}{|l|}{ Goundasheva [sic] et al. (2005) } \\
\hline Population: & $\begin{array}{l}\text { Adult Hanoverian horses ( } 4-9 \text { years) at one Bulgarian veterinary } \\
\text { hospital }\end{array}$ \\
\hline Sample size: & 12 horses \\
\hline Intervention details: & $\begin{array}{l}\text { - Vaccinated for EHV1\&4 and EIV } 12 \text { month after initial } \\
\text { vaccination (control group) [n=6] } \\
\text { - Vaccinated for EHV1\&4 and EIV } 12 \text { months after initial } \\
\text { vaccination and exercised for } 4 \text { days commencing } 14 \text { days } \\
\text { after booster vaccination [ } n=6 \text { ] }\end{array}$ \\
\hline Study design: & Randomised controlled trial \\
\hline Outcome studied: & $\begin{array}{l}\text { White blood cells (WBC), band neutrophils, segmented neutrophils, } \\
\text { eosinophils, monocytes and lymphocytes, cortisol and antibody } \\
\text { titers against EHV1\&4 and EIV were determined on days } 17,18,19 \text {, } \\
21 \text { and } 28 \text { after booster vaccination, corresponding to days } 0,1,2,4 \\
\text { and } 11 \text { after cessation of exercise. } \\
\text { Results were presented as mean +/- SEM }\end{array}$ \\
\hline $\begin{array}{l}\text { Main findings: } \\
\text { (relevant to PICO question): }\end{array}$ & $\begin{array}{l}\text { 1. Kinetics of antibody titers in response to booster vaccination } \\
\text { were similar between groups } \\
\text { 2. Lymphocyte counts increased in the vaccine only group on } \\
\text { days } 17,18 \text { and } 28 \text { after revaccination } \\
\text { 3. In the vaccine and exercise group band neutrophils counts } \\
\text { increased and segmented neutrophils decreased on day } 18 \\
\text { after revaccination (day } 1 \text { after cessation of exercise) }\end{array}$ \\
\hline Limitations: & $\begin{array}{l}\text { - No data was presented for serum cortisol concentration } \\
\text { other than } 0 \mathrm{~h} \text { and } 2 \mathrm{~h} \text { after cessation of exercise in the } \\
\text { exercise group } \\
\text { - } \text { Randomisation process was not described } \\
\text { - Small group size } \\
\text { - While trends in various leucocyte counts are reported, no } \\
\text { comment is made as to whether these lie outside the } \\
\text { published reference ranges for the appropriate laboratories } \\
\text { - Level of preceding fitness prior to study inclusion was not } \\
\text { reported }\end{array}$ \\
\hline
\end{tabular}

(B) Gundasheva (2015)

\begin{tabular}{|r|l|}
\hline Population: & $\begin{array}{l}\text { Adult Hanoverian geldings (4-9 years of age) at one Bulgarian } \\
\text { veterinary hospital intussusception within 3 days of initial surgical } \\
\text { reduction. }\end{array}$ \\
\hline Sample size: & 15 horses \\
\hline
\end{tabular}




\begin{tabular}{|c|c|}
\hline Intervention details: & $\begin{array}{l}\text { - Vaccinated for EHV1\&4 and EIV } 12 \text { months after initial } \\
\text { vaccination [n=6] } \\
\text { - Vaccinated for EHV1\&4 and EIV12 months after initial } \\
\text { vaccination and submitted to physical exercise for } 4 \text { days } \\
\text { commencing } 14 \text { days after revaccination }[n=6] \\
\text { - Control group of unvaccinated animals [ } n=3]\end{array}$ \\
\hline Study design: & Randomised controlled trial \\
\hline Outcome studied: & $\begin{array}{l}\text { Albumin, alpha, beta and gamma globulin serum protein fractions } \\
\text { were determined in all groups on days } 14 \text { and } 17,18,19,21 \text { and } 28 \\
\text { after booster vaccination corresponding with days 1, 2, } 4 \text { and } 11 \\
\text { after cessation of the exercise program. } \\
\text { Results were reported as mean +/-SEM }\end{array}$ \\
\hline $\begin{array}{l}\text { Main findings: } \\
\text { (relevant to PICO question): }\end{array}$ & $\begin{array}{l}\text { Statistically significant difference were noted for albumin, alpha } 2 \\
\text { and beta } 1 \text { and } 2 \text { globulins between booster, vaccinated and } \\
\text { booster, vaccinated and exercised horses at individual time points } \\
\text { but these differences did not persist over the timeframe of the } \\
\text { study. Beta } 2 \text { globulins were reported as reduced in the exercise } \\
\text { group at certain time points whereas all other parameters were } \\
\text { increased in the exercising group. } \\
\text { All parameters remained with the published reference ranges at all } \\
\text { time points for the reporting laboratory. }\end{array}$ \\
\hline Limitations: & $\begin{array}{l}\text { - No data was collected during the first } 14 \text { days post booster } \\
\text { vaccine } \\
\text { - Small group size } \\
\text { - } \quad \text { Randomisation process was not described } \\
\text { commencement of the trial was not discussed }\end{array}$ \\
\hline
\end{tabular}

\begin{tabular}{|c|c|}
\hline \\
\hline \multicolumn{2}{|l|}{$\begin{array}{r}\text { Gundasheva and Georgieva (2015) } \\
\text { Population: }\end{array}$} \\
\hline Sample size: & 15 horses \\
\hline Intervention details: & $\begin{array}{l}\text { - Vaccinated for EHV1\&4 and El } 12 \text { months after initial } \\
\text { vaccination [n=6] } \\
\text { - Vaccinated for EHV1\&4 and El } 12 \text { months after initial } \\
\text { vaccination and submitted to physical exercise for } 4 \text { days } \\
\text { commencing } 14 \text { days after revaccination }[n=6] \\
\text { - Control group of unvaccinated animals [ } n=3]\end{array}$ \\
\hline Study design: & Randomised controlled trial \\
\hline Outcome studied: & $\begin{array}{l}\text { Haptoglobin, fibrinogen and erythrocyte sedimentation ratio were } \\
\text { evaluated in all groups on days } 14 \text { and } 17,18,19,21 \text { and } 28 \text { after } \\
\text { booster vaccination, corresponding with days 1, 2, } 4 \text { and } 11 \text { after } \\
\text { cessation of the exercise program. } \\
\text { Results were reported as mean +/-SEM }\end{array}$ \\
\hline
\end{tabular}




\begin{tabular}{|c|c|c|}
\hline $\begin{array}{l}\text { Main findings: } \\
\text { (relevant to PICO question): }\end{array}$ & 4. & $\begin{array}{l}\text { Plasma haptoglobin was not significantly different at any } \\
\text { time point between the vaccinated, and the vaccinated and } \\
\text { exercised groups. } \\
\text { Fibrinogen concentration was significantly different } \\
\text { between the vaccinated, and vaccinated and exercised } \\
\text { group at day } 1 \text { post cessation of exercise, increasing in the } \\
\text { exercise group but not significantly different at any other } \\
\text { time point during the study. } \\
\text { Haptoglobin and fibrinogen remained within the reference } \\
\text { range for the laboratory in all horses throughout the study } \\
\text { period. } \\
\text { Erythrocyte sedimentation rate (ESR) were significantly } \\
\text { different between the vaccinated only and vaccinated plus } \\
\text { exercised group, increasing in the vaccinated plus exercised } \\
\text { group on days } 1 \text {, and } 4 \text { after cessation of exercise, but not } \\
\text { day } 2 \text {. } \\
\text { Reference ranges for haptoglobin and fibrinogen } \\
\text { concentrations were not presented. }\end{array}$ \\
\hline Limitations: & & $\begin{array}{l}\text { Randomisation process was not discussed } \\
\text { For horses in the revaccination only and revaccination plus } \\
\text { exercise groups, it was unclear whether the prior } \\
\text { vaccination } 12 \text { months preceding the commencement of the } \\
\text { study, was a primary course or booster vaccination } \\
\text { Small group size } \\
\text { Level of preceding fitness prior to study inclusion was not } \\
\text { reported }\end{array}$ \\
\hline
\end{tabular}

\section{Appraisal, application and reflection}

There is no evidence available comparing performance levels in three day event horses receiving either biannual or annual booster vaccinations against equine influenza virus. There is no evidence available evaluating performance levels in three day event horses receiving booster vaccination for equine influenza virus or placebo controls.

Only low quality evidence is available from a group of five papers from one veterinary teaching hospital evaluating a variety of physical and clinicopathological variables in adult warmblood horses after either booster vaccination against equine influenza virus and equine herpes virus and rest or booster vaccination followed by a controlled exercise program for 4 days commencing 14 days after vaccination. Variables evaluated included:

- heart rate*, respiratory rate* and total red blood cell count * (A - Gundasheva, 2015)

- Serum proteins (albumin*, alpha 1 , alpha $2^{*}$, beta $1^{*}$ and beta $2^{*}$, gamma globulins) (B - Gundasheva, 2015)

- Fibrinogen*, haptoglobin erythrocyte sedimentation rate (Gundasheva and Georgieva, 2015)

- Total white blood cell, eosinophil, neutrophil* and lymphocyte* counts (Goundasheva [sic] et al., 2005)

- Lysozyme*, classical and alternate complement activation* (Sotirov et al., 2004)

Statistically significant differences $(P<0.05)$ were noted in the above variables $\left(^{*}\right)$ at intermittent time points in the 14 days post exercise (corresponding to 18-31 days post booster vaccination.) Values were reported as means in all cases with mean plus standard error of mean in some publications. Confidence limits were not reported in any of the studies. Reported values remained within the published reference ranges for the conducting laboratories at all time points when these were reported in the studies. While the above variables are commonly evaluated in horses with reduced performance, athletic performance was not directly evaluated. 
The study participants were reported as male (Goundasheva [sic] et al., 2005) (Sotirov et al., 2004), male entire (A - Gundasheva 2015) geldings (B - Gundasheva 2015) or not reported (Gundasheva and Georgieva 2015) and previous level of fitness prior to study inclusion was not discussed in any study. In all trials an exercise period of 4 days was used, which is likely to vary greatly to training programs for competing three day event horses. While all study horse were reported as being previously vaccinated for equine influenza virus and equine herpes virus $1 \& 4$ a year prior to inclusion in the trial, whether this was a booster or primary vaccine course was not discussed. All trials involved booster vaccination with an oil adjuvanted intramuscular vaccine and therefore these finding may not be relevant to horses receiving intranasal/immune stimulating complex (ISCOM) vaccines/vaccines containing varying influenza strain or vaccines containing equine influenza only.

\section{Conclusions:}

There is no evidence that biannual equine influenza vaccination compared to annual booster vaccination is associated with reduced performance in three day event horses. The quality of the data in adult warmblood horses in the 28 days period post booster vaccination where exercise occurred on days 14-17post vaccination is insufficient to determine whether athletic performance was affected during this period. More definitive conclusions on vaccination protocols in three day event horses cannot be drawn until higher quality evidence is available on the topic.

\section{Methodology Section}

\begin{tabular}{|c|c|}
\hline \multicolumn{2}{|l|}{ Search Strategy } \\
\hline $\begin{array}{r}\text { Databases searched and dates } \\
\text { covered: }\end{array}$ & $\begin{array}{l}\text { PubMed NCBI Platform 1973-2018 Week } 16 \\
\text { CAB Abstracts on OVID Platform 1973-2018 Week } 16\end{array}$ \\
\hline Search terms: & $\begin{array}{l}\text { PubMed } \\
\text { 1. equine* or horse* or equus or equid* or mare or mares or pony } \\
\text { or ponies or exp equidae/ or exp equus/ or exp horses/ or exp } \\
\text { mares/ } \\
\text { 2. 'three day event*' or 'show jump*' or dressag* or endur* or } \\
\text { exercis* or sport* or compet* or athlet* or 'cross country' } \\
\text { 3. exp show jumping/ or exp horse riding/ } \\
\text { 4. (1 and } 2 \text { ) or } 3 \\
\text { 5. vaccin* or immunisation or immunization or inoculation or exp } \\
\text { vaccination/ or exp immunization/ } \\
\text { 6. influenza or flu or exp influenza/ } \\
\text { 7. } 4 \text { and } 5 \text { and } 6 \\
\text { CAB Abstracts } \\
\text { 1. equine OR horse OR mare OR mares OR broodmares OR pony OR } \\
\text { ponies } \\
\text { 2. three day evening OR show jumping OR dressage OR endurance } \\
\text { OR exercise OR sport OR sporting OR competition OR athlete OR } \\
\text { athletic OR cross country } \\
\text { 3. influenza OR flu } \\
\text { 4. vaccine OR vaccination OR immunisation OR immunization OR } \\
\text { inoculation } \\
\text { 5. } 1 \text { and } 2 \text { and } 3 \text { and } 4\end{array}$ \\
\hline Dates searches performed: & 01 May 2018 \\
\hline
\end{tabular}




\begin{tabular}{|c|c|}
\hline \multicolumn{2}{|l|}{ Exclusion / Inclusion Criteria } \\
\hline Exclusion: & $\begin{array}{l}\text { Non English language papers } \\
\text { Single case reports } \\
\text { Book chapters and literature reviews without novel information } \\
\text { Not relevant to the question }\end{array}$ \\
\hline Inclusion: & $\begin{array}{l}\text { Papers comparing physical or clincopathological data, in sports } \\
\text { horses exercising after revaccination for equine influenza or equine } \\
\text { influenza and equine herpes virus } 1 \& 4 \text { were evaluated. Due to the } \\
\text { absence of published data in sports horses after biannual } \\
\text { vaccination for El, varying vaccination protocols were included. }\end{array}$ \\
\hline
\end{tabular}

\begin{tabular}{|c|c|c|c|c|c|c|}
\hline \multicolumn{7}{|c|}{ Search Outcome } \\
\hline Database & $\begin{array}{l}\text { Number } \\
\text { of } \\
\text { results }\end{array}$ & $\begin{array}{l}\text { Excluded - } \\
\text { [Non } \\
\text { English } \\
\text { Language] }\end{array}$ & $\begin{array}{l}\text { Excluded - } \\
\text { [single case } \\
\text { report] }\end{array}$ & $\begin{array}{c}\text { Excluded - } \\
\text { [Narrative } \\
\text { review/opinion } \\
\text { pieces] }\end{array}$ & $\begin{array}{l}\text { Excluded - [not } \\
\text { relevant to } \\
\text { PICO] }\end{array}$ & $\begin{array}{l}\text { Total } \\
\text { relevant } \\
\text { papers }\end{array}$ \\
\hline $\begin{array}{l}\mathrm{CAB} \\
\text { Abstracts }\end{array}$ & 188 & 37 & 2 & 5 & 139 & 5 \\
\hline $\begin{array}{l}\text { NCBI } \\
\text { Pubmed }\end{array}$ & 25 & 2 & 0 & 0 & 22 & 1 \\
\hline \multicolumn{6}{|c|}{ Total relevant papers when duplicates removed } & 5 \\
\hline
\end{tabular}

\section{CONFLICT OF INTEREST}

The author declares no conflicts of interest.

\section{REFERENCES}

1. Goundasheva[sic], D., Chenchev, I., Katsarova, R., Karadiov, T., Tsachev, I., Barzey, G. (2005). "Changes in leukocyte and antibody response following exercise in horses with booster vaccination against influenza and herpes virus 4/1." Revue de Medecine Veterinaire 156(11): 527-532.

2. (A) Gundasheva, D. (2015). "Effect of exercise on erythron, heart and respiratory rates in horses vaccinated against equine herpes virus $4 / 1$ and equine influenza virus." Comparative Clinical Pathology 24(6): 1565-1572. DOI: http://dx.doi.org/10.1007/s00580-015-2117-9

3. (B) Gundasheva, D. (2015). "Electrophoretic Analysis of Serum Proteins in Strenuously Trained Horses Revaccinated Against Equine Herpes Virus 4/1 and Equine Influenza Virus." Veterinarija ir Zootechnika 69(91): 18-25. 
4. Gundasheva, D., \& Georgieva, T. (2015). "Changes in some acute phase response parameters after physical exercise in horses with booster vaccination against equine herpes virus $4 / 1$ and equine influenza virus." Veterinarija ir Zootechnika 70(92): 22-28.

5. Sotirov, L., Goundasheva, D., Dzheleboy, P. (2004). "Lysozyme and complement response to exercise in horses with booster vaccination against influenza virus and equine herpes virus 1 and 4 ." Revue de Medecine Veterinaire 155(8/9): 449-452.

\section{Acknowledgement}

RCVS Knowledge was supported in producing this Knowledge Summary by an educational grant from Petplan Charitable Trust. 


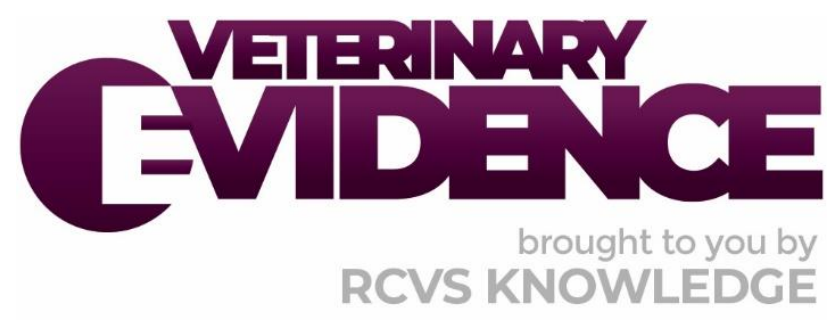

\section{Intellectual Property Rights}

Authors of Knowledge Summaries submitted to RCVS Knowledge for publication will retain copyright in their work, and will be required to grant RCVS Knowledge a non-exclusive license of the rights of copyright in the materials including but not limited to the right to publish, re-

publish, transmit, sell, distribute and otherwise use the materials in all languages and all media throughout the world, and to license or permit others to do so.

\section{Disclaimer}

Knowledge Summaries are a peer-reviewed article type which aims to answer a clinical question based on the best available current evidence. It does not override the responsibility

of the practitioner. Informed decisions should be made by considering such factors as individual clinical expertise and judgement along with patient's circumstances and owners' values. Knowledge Summaries are a resource to help inform and any opinions expressed within the Knowledge Summaries are the author's own and do not necessarily reflect the view of the RCVS Knowledge. Authors are responsible for the accuracy of the content. While the

Editor and Publisher believe that all content herein are in accord with current recommendations and practice at the time of publication, they accept no legal responsibility

for any errors or omissions, and make no warranty, express or implied, with respect to material contained within.

For further information please refer to our Terms of Use.

RCVS Knowledge is the independent charity associated with the Royal College of Veterinary Surgeons (RCVS). Our ambition is to become a global intermediary for evidence based veterinary knowledge by providing access to information that is of immediate value to practicing veterinary professionals and directly contributes to evidence based clinical decision-making.

https://www.veterinaryevidence.org/

RCVS Knowledge is a registered Charity No. 230886.

Registered as a Company limited by guarantee in England and Wales No. 598443.

Registered Office: Belgravia House, 62-64 Horseferry Road, London SW1P 2AF

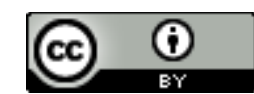

This work is licensed under a Creative Commons Attribution 4.0 International License 